should consiler the strength and rigidity necessary in a sea-going vessel. It would however be unfair to compare her with a ship of modern build of the same size. Even the designation "ship," as applied to her, is apt to convey a false idea. She is in fact a very large sailing rowingboat.

These ancient vessels may be considered as consisting of two distinct sections, each having its special use and function. The portion above the beams is the hold proper, the useful space. Here the crew had their abode, and here was carried probably all that the vessel had to carry, and this portion is comparatively strong. The material is no doubt here also of small dimensions, but what there is has been judiciously distributed, is of good quality, and has been well put together. It should also be remembered that the weight carried was small in quantity as compared to the carrying capacity, and consisted principally of live cargo, and this kind of loading is much less trying to a vessel in a seaway than a similar loading of dead weight would be. The lower portion of the ship, on the other hand, had a different kind of duty to perform. It had to supply the "form" necessary for small resistance and rapid locomotion, and to float the upper section : keeping this in mind it will be found that her construction gives evidence of a great deal of practical skill and ingenuity. Every part of the vessel is sufficiently strong for the duty expected of her, while at the same time economy of weight of material has been studied throughout. It will be seen that the weight of the superstructure is taken entirely by the floor timbers, the ends of the beams resting on them, while the beams are supported amidships by the props stepped in the throats of the floors. There would therefore be very little stress on the ties of the bottom planking, which latter, there being no counteracting pressure on it from the inside, would always tend to cling to the timbers by the pressure of the water outside. The only weight of any moment which would tend to separate the two sections of the boat is the mast, and this tendency is met by the "branch" of the step being secured to the "fish." Still there can be no doubt that this boat must have possessed a pliancy and mobility in a heavy sea which we should look upon as ominous in a modern sea-going craft. Her real safety consisted in a tough and elastic outer skin, which would be the more invulnerable from not being made unduly rigid at any point. Thus her apparent weakness was her real strength. Mr. Archer has not been able to discover anything deserving the name of a bolt in the whole structure. The stoutest iron fastenings are the rivets in the scarfs of the keel and the nails securing the inside knees, and they are no stronger than ordinary 4 -inch spikes.

It seems probable that such a boat would be capable of great speed, even under oars alone; with a fair wind she must have been very fast. Mr. Archer has assumed a low water-line, and finds that at this trim her displacement is 994 cubic feet, or 28.4 tons; area of immersed midships section 24 square feet; extreme length on loadline, 73 feet 3 inches; and draft of water 3 feet 8 inches. Allowing ro tons for her complement of 10o men with their accoutrements, leaves 184 tons for the vessel, with inventory, stores, and equipment, and this allowance is probably ample. The areas of cross-sections are obtained by multiplying the ordinates of the curve by 4 feet.

\section{LEARNED SOCIETIES IN JAPAN}

$I^{\mathrm{T}}$ is now a little more than ten years since Japanese students began to flock in large numbers to the various schools of Europe and America, after the great revolution which completely altered the political, and in many respects the social, organisation of the country. Many of these young men travelled and studied at their own expense; but the majority was selected by the principal Government departments, and the expenses paid from the Imperial funds. For six or seven years the numbers continued without diminution; but soon after the commencement of the Satsuma rebellion in 1877 when the heavy strain on the Imperial Exchequer caused by the suppression of that outbreak began to be felt, it was decided to economise the public expenditure in various ways, and amongst others by reducing the number of those studying abroad at Government expense. The result of this measure, which was forced on the Ministers by unfortunate circumstances, was that many Japanese young men who spent some years in the principal educational establishments of western countries, returned to their own land with a sound training in their respective branches of study. It would not be desirable, even if it were possible, to enter here into the question how far they have fulfilled the hopes with which they were first sent abroad. Many of them have had brilliant careers amongst their foreign fellow-students, and, on the whole, we believe they have done as much as any body of English students, similarly placed, could have in the same time; but it is another question whether they are fitted to assume the places held by the foreign professors and instructors in the various educational institutions of the country. It was to this that the Government looked when they were first despatched to Europe ; but, from a combination of causes, it is doubtful whether the laudable and patriotic desire to be, as far as possible, independent of extraneous assistance, has been so completely fulfilled as was originally anticipated.

One result has undoubtedly attended this great influx of men trained after western methods, namely, the thirst for scientific knowledge of all kinds amongst the educated classes in Japan. It is hardly an exaggeration to say that Japanese literature, as an indigenous product, is for the present almost in abeyance. If we examine the monthly catalogue of books for which licence to print is granted by the Censorate in the Home Department in Tokio, it will be seen that a very large proportion is composed of translations or adaptations of European or American scientific or literary works. Besides translations made at the expense of the public departments, we find private individuals throughout the country utilising their knowledge of a western language by translating from it, for the benefit of their countrymen. Thus, not to mention innumerable "Lives" of Wellington and Napoleon, or translations of "Gulliver's Travels," "Robinson Crusoe," and other books of this description, the works of Huxley, Carpenter, Peschel, Darwin, 'Tyndall, Quatrefages, Lyell, Buckle, Mill, \&c., \&c., have all been translated or adapted with more or less success for the Japanese reader. Societies, on the European model, have also been formed, and it is with these that we are chiefly concerned at present.

Centuries before the Royal Society of Great Britain was founded men interested in the pursuit of some study or accomplishment in Japan had formed themselves in to societies, some of which still exist. Collectors of antiquities, of coins, of the handwriting of celebrated men of ancient times, met at stated intervals to exhibit and discuss the authenticity of their treasures; go-players had their own organisation, with branches in all the chief towns throughout the country, and headquarters in the capital, where the leaders met for trials of skill. These latter even had a kind of magazine in which problems for solution were set, and the moves in remarkable games recorded. These meetings generally took place in the evening, at some well-known house of entertainment. There was no formal reading of papers, with discussions afterwards ; a member exhibited some new object, related briefly all he knew about it, and asked for any further information that could be afforded by those present. Frequently also these meetings were used for effecting 
sales or exchanges amongst the members. Some of these old societies still flourish in undiminished vigour, unaffected by the changes which have passed over the country and altered all around them. Amongst these are the $K \ddot{o}$-butsu-sha, or Antiquarian Society, the Numismatic Society, the Association of Go-players, and many of the old assemblies for literary and poetical contests. But the new era has been productive of societies of a more scientific kind, based on the models of learned associations in Europe and America. Founded by students fresh from abroad, they have received the support of men of wealth and eminence, and, judging from the experience of the past few years, they seem in a fair way to attain permanent success.

The most important of these associations is the Geographical Society of Tokio, which now numbers about 200 members. The subscriptions, which are very small, are largely increased by donations from the wealthy members. It is under the patronage of several of the imperial princes, and among its members are the chief personages of the Empire. The Transactions are neatly printed in small pamphlets of about Ioo pages each, and contain much matter which would be valuable even to European geographers. With the exception of China, Japan is the only foreign country having intercourse with Corea. Our information respecting this peninsular kingdom is limited to the imperfect accounts of the Jesuit priests; but the Japanese Geographical Society has already had several interesting and important papers on the subject from its members. The difficulties of the language seriously restrict the circulation of these and other papers, but we believe the Committee are contemplating the publication of translations of their Transactions.

During his too brief stay in Japan as occupant of the Chair of Zoology in the University of Tokio, Prof. Morse of Salem, Massachusetts, was instrumental in establishing a Biological Society which attracted much attention. It is now being conducted successfully by Prof. Yatabe, a Japanese gentleman educated in the United States.

Another association, which is, we believe, unique among the societies of the world, is the Kojunsha, or Society for the Circulation of Knowledge. Its head-quarters are at Tokio, but there are branches in every town of importance in the Empire. It possesses a secretary and staff of clerks, and a member desiring to obtain information on any subject applies to the secretary. The latter has on his books the names of all the members likely to be able to satisfy the applicant, and immediately transmits the question to them. The answers are forwarded in due course to the inquirer, and should the subject be deemed by the Committee of sufficient general importance, the whole is printed in the weekly Journal of the Society. The pains which are taken to obtain satisfactory replies to queries are, we can vouch from personal experience, almost incredible. It is not surprising to learn that this Society has nearly 3000 members scattered throughout the Empire, and even in Europe and America. As a device for bringing together the active and inquiring minds of the country, it is almost unequalled. The subscription, which includes the use of reading-rooms and the numbers of the Journal, is about balf-a-crown per month.

The Numismatic Society, to which we have already referred, is also very active. It publishes a periodical describing new and strange coins that have been exhibited at its meetings, and supplies other information interesting to collectors.

We need not refer here to the English and German Asiatic Societies founded in Yokohama and Tokio. They are under the control of foreign residents, their papers are in a foreign tongue, and, although their work has been most valuable, they are outside the scope of the present article. Nor need we give more than a passing reference to the innumerable political societies which have sprung up like mushrooms in all parts of the country during the past few years. If the objects of the promoters of these organisations were less palpably selfish, and more in accordance with their high-sounding titles, they would be very important instruments in the education of the people.

But we cannot pass over the latest scientific association of Japan. The Seismological Society, as its name indicates, is founded for the purpose of investigating volcanic and earthquake phenomena of all kinds. Japan is particularly well situated for this object. There are numerous active and extinct volcanoes throughout the island. Mild earthquakes are of very frequent occurrence, so that the student has not, on the one hand, to wait months for bis subject, as in most parts of Europe, or, on the other, to run for his life when it does come, as in South America. This society was founded chiefly through the energy of its vice-president, Mr. Milne, professor of geology in the Engineering College at Tokio, who has long made seismic phenomena a special study. A Japanese, Mr. Hattori, himself a student of the subject, is President of the Association, which numbers many foreigners amongst its members. The Central Government have throughout taken a warm interest in the success of the Society, and have, we believe, placed the telegraph lines at its disposal, and ordered the locaI officials all over the country to report all occurrences connected with earthquakes and volcanic eruptions in their districts. A few months since, under the auspices of the Society, an exhibition of seismological instruments of various kinds-one of them as ancient as A.D. I26took place in Tokio. The number of visitors in one day to the rooms was over 2000 , a fact which attests the interest taken in this study by the Japanese. The Transactions of the Society are published in English in the Fapan Gazette newspaper of Yokohama.

The army, navy, and other professions have their own societies and newspapers, very much as in England. One of the most curious of these class or trade journals is the dancing-girls' paper, containing portraits and biographies of the chief danseuses. We have not advanced so far yet in England as to have an organ-grinders gazette!

On the whole it must be pronounced that the outlook for the propagation of scientific knowledge in Japan is hopeful; and there seems no reason to fear that science will suffer greatly after the approaching and inevitable departure of all foreign instructors in the country. They will leave behind men who, although possibly not such efficient teachers, are animated by all the thirst for knowledge that animates the bulk of scientific men in western lands.

\section{NOTES}

DR. C. W. Siemens has received from the French Government a frmal document nominating him "Officier de l'Instruction Publique," the nomination being accompanied by the insignia of the order, which corresponds, we believe, to the Prussian order "Pour le Mérite."

IT is proposed to open an International Electrical Exhibition at the Crystal Palace in December.

THE anatomical department of Edinburgh University has lost a valuable servant in the death, at the age of seventy, of Mr. A. B. Stirling, the assistant conservator of the Anatomical Museum. He was born in $x 8 \mathrm{I}$ at Milngavie, Stirlingshire, where his fathe $\mathrm{r}$ was a shoemaker. Stirling early evinced a decided liking for natural history studies; he was a born naturalist. His love of natural history brought him into contact with the late Prof. John Reid and Dr. Adamson of St. Andrews, who employed him to 